\section{PHILOSOPHICAL APPROACH TO CONSERVATION OF BUDDHIST MONASTERY IN THAILAND}

\section{Pinraj Khanjanusthiti ${ }^{1}$}

\begin{abstract}
The degree of repair and conservation of a historic building often creates controversy. Guidelines and principles in conservation such as international charters and manifestos of various conservation movements can generate inconclusive debates. A philosophical approach to conservation is based on the value given to the monument and site, since the aim of conservation is "...the upkeep and maintenance of historic buildings and areas that merit care either due to their cultural significance or due to their social and economic values "(Jokilehto 1992 : 109). It is obvious that we want to conserve what we value. Therefore, if the values of a historic monument a re agreed u pon, planning for its conservation should not create much argument.
\end{abstract}

The Venice Charter of 1964 emphasises that the aim of the conservation process is to preserve and reveal the authenticity, including the archaeological and historical value, of the monument. Such values, however, are always debatable, since historic value can refer to the historic fabric of the monument as well as the historical association between the monument and the society. In the former aspect, physical elements will be preserved or restored with

${ }^{1}$ Ph.D., Assistant Professor, F aculty of architecture, Chulalongkorn University, Bangkok respect to the original materials, techniques, and nature of the monument as an authentic document. In the latter case, the historical value may be represented by a living spirit and the continuity of symbolic associations, while the authenticity of the architectural fabric is not taken into account.

In the case of Thailand, where Buddhist monasteries have been built, restored or rebuilt as acts of piety, it is obvious that the spiritual aspect of the monument is of great importance and may be considered to overshadow archaeological, historic, and architectural values. In this article, we will look at how this philosophical approach to conservation has developed by exploring the attitudes of Thai Buddhists towards their built environment. Understanding this will lead to a determination of the spiritual values, such as identity and authenticity, of historical monuments.

\section{Values of Cultural Heritage}

There are two main categories involved in the value of cultural heritage : the transcendent or spiritual value, and the material a nd financial values. $T$ he Management Guideline for World Cultural Heritage Sites divides values into two groups. The first one is cultural value, consisting of identity, artistic, technical, and rarity values. The other is contemporary socio-economic values which include economic, functional, educational, social, and political values. The values of a historic monument are multifaceted. They have both positive and negative effects on the monument. Emphasis on the economic value of a monument can bring about a loss of cultural value. It is important for professionals dealing with historic monuments to have a clear understanding of these values in order to formulate a successful conservation plan. It is 
important that existing values be retained and that the positive value from the intervention be comparable to or outweigh the loss of the old one.

The values of cultural heritage are subjective, and therefore, the cultural background of each society has a direct influence over this determination. A value can be defined in terms of one's beliefs about what is desirable and what is undesirable. Values are social and cultural products. The values that an individual gives to historic buildings depends very much on his/her attitude towards the past, since historic buildings can be regarded as relics of the past, links between the reality of the present and an imaginary long gone past. Therefore, it is necessary to understand the value of the past as perceived by people of different social and cultural backgrounds.

\section{Different Attitudes towards Built Environment}

The western idea of restoring a religious building to its original splendour as an act of worship can be paralleled with the eastern concept of repairing and restoration. However, eastern and western attitudes towards architectural fabric are very different. In the east, once a building is consecrated, the fabric of that building becomes sacred along with its interior and exterior space. Even if the style has changed over time as a result of repairs or restoration, the architecture is still considered as a part of the sacred realm. Restoration is seen as a continuation of the religious life, style and craftsmanship. In the west, by contrast, the emphasis is on the physical representation of sacred architecture. The preference for a particular style of architecture as appropriate to a house of God has led to the destruction of building features that are in the style of other periods.

The attitudes towards religious buildings of the medieval man in Europe and present-day observers in the east are similar. Both are based on the mentality of 'traditional civilization'. It is suggested that the difference between the east and the west occurred when western thought and actions deviated from their 'traditional civilization'.

"...no ground for the radical opposition between East and West so long as that there were traditional civilizations in the West as well as in the East; the opposition only takes on significance with the appearance of the specifically modern West, since it is much more an opposition of two mentalities than of two more or less clearly defined geographical entities. During certain periods, among which the nearest to our times is the medieval period, the Western mentality, in its more important features, was far more akin to the Oriental mentality as it has remained up to the present day than what it has itself become in modern time" (Guenon 1975: 17 ).

In civilizations with a traditional character, religions occupy the principle position to which everything else can be referred. Christianity was the backbone of medieval thought and action. Metaphysical doctrine constituted the essential. Everything else was linked to it as consequences of absolute reality. Revolutionary scientific discoveries in the Renaissance period as well as an interest in the humanities shifted the emphasis from God to Man. Scientists 
defined the basic laws of physics and mathematics as keys to understanding the universe.

Newly invented science and technology also changed attitudes towards the world. Machinery such as the windmill, pump, pulley, clock, and optical lenses enabled man to gain access into another facet of the natural world. The ancients conceived the universe as an 'intellectual organism' while man was regarded as an entity within this organism. The knowledge of science and technology changed the attitude of man towards the universe, since man could observe, measure, 1 earn the laws of motion, and gain knowledge of how the universe works. The cosmos became one great system of cause and effect. Accordingly, there was no necessity to base their beliefs on the purpose or meaning of a transcendent character. Eliade writes that the modern discoveries of physics and chemistry, and the subsequent transformation of the world by industrial society, represents the 'desacralization' of the cosmos by scientific thought (Eliade 1961 :51).

Guinon defines those traditional sciences which are an application of the metaphysical doctrine as 'sacred science', and the modern sciences as 'profane science', having risen out of material reality. He also compares this division of science to other forms of art. He states:

"What is true of all the sciences in this respect is equally true of every art, in as much as an art can possess a genuinely symbolical value which enable it to serve as a support for meditation, and also because its rules, like the law which it is the object of science to understand, are in their turn reflections and applications of the fundamental principles; and thus it is that in every normal civilization there are 'traditional arts', which are no less lost to the modern West than the traditional sciences" ( Guenon 1957: 49).

\section{The Functions of the Past}

Amid technological advances and the development of knowledge for the wellbeing of humanity in the future, men still look back to the past. Men have always been searching for the thing that they have lost or been deprived of, so it is understandable that modern man, losing his foothold in the chaotic world, unable to identify with the environment, looks back to his roots in order to make sense out of a senseless life. Searching for the past is not a modern phenomenon. In every period of history and in every aspect of human life, the past has been used as a model for the future, a guide, as well as an imaginary place for escape from unpleasant reality. This can be seen in the revival of architectural style, the Art and Crafts movement against industrialization, the emerging of the theme museum, and the heritage industry.

Past, present, and future are entwined. It is suggested that the world that man lives in transcends the limitations of the immediate human environment, since the world comprises not only present but past as well as future. The loss of any of these dimensions is a detachment from one part of reality (Mumford 1963: 12). Human experiences of their present and their activities that result in their future are related indirectly to their experiences, perceptions, and management of the past.

The sense of identity and the characteristics of human beings are also formed by their experience of the past. It is stated that the past is integral to our sense of iden- 
tity. An ability to recall and identify with one's past gives one's existence meaning, purpose, and value (Lowenthal 1990: 41). The realization of our existence is the necessary condition for our living in this world. Men realize their existence and feel 'at home' with their environment by interpreting symbols and understand their meanings by using their recollections.

In Victorian England, where several streams of thinking about conservation emerged, there was a realization of a new meaning of the past. At that time, industrialization and the invention of new technologies had changed the cultural and physical landscape at a dramatic pace. The juxtaposition of new industrial and commercial buildings with the old townscape and medieval ruins was commonplace in most English towns. The Victorians had to cope with changes not only to their built environment but also to their social and cultural values. Therefore, the past and history were seen as a device to provide a sense of place and identity. It has been suggested that :

" The exploration of the histories of artifacts, buildings, families, and communities helped individuals...deal with the dominion of change by deepening their sense of place and orientation and fabricating a sense of historic continuity" (Dellheim 1982 : 57 ).

\section{Eastern Historical Concept}

There is a link between the concept of time and historical consciousness. It is suggested that the east did not grasp the concept of time quantitatively; for instance, historical books with accurate dates are rare ( Nakamura 1971 : 81 ). Eastern history is not the product of historical science but rather a work of art or religious document. The w riting of $B$ uddhist Books of Ordination is cited as an example of nonhistorical thinking. The new patimok rules were written after the death of the Buddha in order to meet changing social conditions. These rules were a dded as a supplement to the patimok but were claimed to have the authority of the Buddha's own teaching. It is concluded that historical evidence was ignored because :

" Their concern for the proper observance of the precepts and of the rites preceded and was stronger than their regard for historical accuracy" ( Nakamura 1971 : 146 ).

No matter how the past was recorded, it has been used to serve various purposes. It is suggested that there are two uses of the past by Thai people: the past as sanction and as destiny ( Tambiah $1977: 528$ ). The past in the former case is used as the 'legitimator of the present'. Tambiah suggests that in this case the past is seen as living present. We can see several examples throughout history. History has been used by ancient kings and modern governments to justify their activities and strengthen their power.

When the king of Ayutthaya adopted the God-king concept, historical traditions based on Buddhism and Brahmanism as well as architecture were revived and adopted. King Prasatthong was a usurper of the throne. During his reign several art and architectural works were produced that were based on the revival of ancient traditions in order to legitimize the king's position a s a God-king as well as a Dhammaraja. The king built several Buddha images decorated with imperial 
costume. It is suggested that the king wanted to revive the Mahayana Buddhist concept of a 'Chakravarti' or Buddhist emperor, a continuous tradition practised by later kings until the Bangkok period (Vallibhotama 1981 : 44). He also built a summer palace which was planned after a Hindu-Khmer architectural model. The planning represented the Sumeru Mountain which is the centre of the universe according to Hindu concepts. Again, the king created the universe where he was represented as a god in the same way as the ancient Khmer kings had done before him.

We can see that the revival of the past in history is also a revival of ideologies in order to create new traditions as well as new art and architecture. However, at present, the use of the past as a legitimator of the present also includes the use of relics of the past. The reason for using the past to serve the present has also changed. The political power of kings and the state are not as important as economic considerations.

\section{Western Concepts of Time and History}

Time for an archaic man could be divided into two types: historical time, which man experienced in everyday life, and sacred time which is represented by myth and rituals. The difference between the two is the quality of the experience. While man experiences the changes of individual and chronological time, sacred time cannot be measured because it transcends the profanity of the human condition and has no duration(Eliade $1961: 58$ ). The division of time into sa cred and profane is a fundamental concept of every religion. Man found that, apart from the simple rhythms of nature and the human body, there is also the far greater rhythm of the universe that is regulated by a transcendental power.

In the west where the Christian faith is dominant, the concept of time and the value of the past, present, and future derived from two significant world orders: the Greek and the Hebrew. For the ancient Greeks, time is regarded as the 'highest principle of order'. For ancient Greek philosophers, time gave unity and rhythm to the chaotic formlessness of nature that was regulated entirely by sensation and appetite (Dillstone 1955: 80). Time was also seen as the 'moving likeness of eternity' which was created by the Supreme Power, explained as follows:

"When the father who had begotten the world saw it set in motion and alive, he rejoiced and being well pleased he took thought to make it yet more like its pattern. So, as the pattern is the Living Being that is for ever existent, he sought to make this universe also like it, so far as might be, in that respect. Now the nature of that Living Being was eternal, and this character it was impossible to confer in full completeness on the generated thing. But he took thought to make, as it were, a moving likeness of eternity; and at the same time that he ordered the Heaven, he made, of eternity that abides in unity, an everlasting likeness moving a ccording to number that to which we have given the name Time" ( Timaeus cited in Dillstone 1955 : 80 ).

Time was also like motion. Aristotle defines time as 'number of movement in respect of the before and after'. 
In the Hebrew tradition, time is not only continuous rhythm but is punctuated with significant moments. Amoment in time is seen as 'victory of order over chaos', of the emergence of a cosmos out of a primal formlessness, of the imposition of form upon material which is without form and space. Particular moments of time possess a particular quality of experience either good or bad. Important events in time are represented by important events such as festivals and rituals. The idea of significant events as the markers of time leads to an interest in the relationship of the past to the present. This is because events can happen repeatedly. Man has a responsibility to keep in mind the great events of the past, to recall, celebrate, and look for their recurrence (Dillstone 1955: 86 ). According to this idea, history becomes an important symbol of time. It signifies that time is not a monotonous continuity but rather a context where outstanding events happen and through which the meaning of life is identified.

The metaphysical doctrine constitutes the principle to which other subject matter can be referred. It forms the world-view of the west towards its past, present, and future. The significance of history and of the values given to the past, therefore, are different from the eastern ones, which refer to another set of doctrines.

\section{Eastern Concept of Time}

There are two divisions of time according to Buddhism: historical time and cosmic time. Both of them are superimposed. As in many archaic societies, the symbolism of cosmic time was represented by myth. The myth of time in ancient India predated Buddhism and can be attributed to the religious approach to the subject of time. It is explained in the Indian myth of time that cosmic time comprises cycles. There are periods of creation and destruction of the universe within these cycles. The smallest unit of measurement of a cycle is the 'yuga' or 'age'. Each is preceded by a 'dawn' and followed by a 'dusk'. Four yugas comprise one complete cycle, a 'mahayuga'. Each of the 'yugas' is different in duration as well as the life span of the human being in the yuga. At the end of a mahayuga, there is a dissolution or 'pralaya', after which another yuga begins. Cycles of creation, destruction, and re-creation go on to the thousandth cycle where, at the end of the cycle, a great dissolution, 'mahapralaya', occurs, and the cycle of re-creation is repeated again. As the present Dalai Lama sug-gests, Buddhists do not believe in one Big Bang, they believe in many Big Bangs (Lopez $1995: 14)$.

In Buddhism, time is reversible. The enlightenment of the Buddha is the indication of breaking out of samsara or out of the wheel of existence. It is interpreted that in this way, the Buddha transcended both cosmic space and cyclic time (Eliade 1961 : 78). The idea of reversible time can be seen in Thai history. In the year 1638, King Prasatthong of Ayutthaya (reign 1629-1659) abolished the Siamese Lesser Era (the Chulasakaraj) because that year was the year 1000 , which, according to the Buddhist legend of time, coincided with the beginning of the Kaliyuga, an inauspicious and evil age. Every Buddhist citizen of Ayutthaya knew of the disastrous events that, according to the scriptures, were bound to happen. The king, as the protector of the kingdom and his subjects, organized major religious rituals both Brahmanistic and Buddhist to abolish the old era and start a new one. The change of era not only raised the morale of the people but also fortified the power and symbolism of the king as Dhammaraja and as a God-king who 
transcended the cycle of time.

The concept of cyclical or reversible time is often given as an explanation of the difference between eastern and western ideology. Westem linearperception of time emphasises the temporal qualities of objects and events. In the case of historic buildings, the fabric of the architecture is seen as important. By contrast, the eastern concept of cyclical time venerates the conception of the place rather than the material object that is built on it (Menon 1994:39). This assumption is developed not only from the concept of reversible time but also the use of the concept of time in explaining the other characteristics of objects and events.

\section{Concept of Time and the Impermanence of Existence}

It can be argued that we live in historical time and make our judgement on the nature of the existing world by our historical experience. But the experience that forms our world-view is based on our cultural and religious history. The concept of cosmic time is the fundamental principle informing the Buddhist world-view of the existence of all composite things as well as their change and their continuity.

When we come to consider cosmic time again, we will find that the duration of cosmic time can be measured. However, when considered in terms of historical time, it is vast and relatively incalculable. The length of cosmic time, according to Indian mythology, is explained as follows:

"The 12,000 years of one mahayuga has been counted as 'divine years' of 360 years each, which gives a total of $4,320,000$ years for a single cosmic cycle. A thousand such mahayugas constitute one kalpa ( or "form"); 14 kalpas make up one manvantara... One kalpa is equal to one day in the life of Brahma, and an other kalpa to one night. A hundred of these 'years' of Brahma, say 311 thousand billion human years, make up the life of the god. But even this considerable length of Brahma's life does not exhaust the whole of Time, for the gods are not eternal, and the cosmic creations and destruction go on without end."

(Eliade 1961: 65)

From this explanation, it can be concluded that this world is illusory and lacks reality because of its limited duration when compared to cosmic time. The object that we believe to exist in fact is an illusion or maya in the sense that it will not exist in the next ten thousand years.

The non-existence of form or the regarding of form as illusion is the principle of Buddhist philosophy. A characteristic of existence is 'anicca' or impermanence. By the impermanency of things that have become or arisen, we mean that these things never persist in the same way, but that they are vanishing and dissolving from one moment to the next. (Visuddhimagga cited in Ling 1973 : 111). Form and the perception of form are regarded as having an illusory quality. It is explained in a scripture that :

"Form should be seen as a mass of foam, because easily crushed; feeling as a water bubble, because pleasurable only for a moment; perception as a mirage, because delusive; 
volitions as like the trunk of the plantain tree, because without substance; consciousness as a mock show, because deceptive" (Buddhist scripture trans by Conze 1959 : 188-189).

All forms of life, according to the Buddha, possess three common characteristics : impermanence, suffering, and an absence of soul. The law of change applies to all compounded things, including man-made objects and ideas. Change occurs "...from a granite cathedral to a china vase, from a code of laws to an empire, all things rise to their zenith, and then, however slowly, decay towards the inevitable end" (Humphreys $1990: 81$ ).

Since everything in the universe, including the gods, is in a state of flux, resistance to the cosmic flux and craving for permanence where permanence could not be found, leads to the inevitability of sorrow or suffering. This principle of Buddhism forms an important part of a Buddhist's character and his view of the nature of the world.

Architecture, as for any other existence, is impermanent, especially when built of less permanent material such as timber. The decay of the material is normally seen as part of the natural process of a life cycle. Therefore, the traditional repairing of a building often involves the replacement of deteriorated parts with new ones.

\section{Identity and Continuity of Exis- tence}

It has been stated that the emphasis of western conservation is on the fabric of architecture while in the east the spirit of the place is considered to be more important. How did this claim become apparent, and is the conservation of architectural spirit justified? To answer this, we must go back to the metaphysical doctrine which forms the basis of the Buddhist world-view.

In one respect, Buddhism is a 'theory of existence'. Buddhism discourages the concept of the individual and regards the boundaries between one so-called 'individual' and others as artificial ( Ling $1973: 120$ ). The nature of the 'individual' is continuously changing with the passage of time, but possesses an illusory unity through the continuity of the body. This concept is illustrated in Milindapanha, a Pali text r ecording the conversation between a Bactrian king, Milinda, and Nagasena, a Buddhist monk. A question is asked by the king to which the explanation for the continuity of identity is given by Nagasena:

"Does a man who was born remain the same being or become another?"

"He neither re mains the same nor becomes another, your Majesty"

Then Nagasena compares the identity of an individual to the flame of a lamp. The flame that burns at the beginning of the night is not the same as the one at the end. However, it is the same lamp that gives light all through the night. Similarly, the continuity of phenomena is kept up. "One comes into existence, another passes away and the sequence $r$ uns continuously without self-conscious existence, neither the same nor yet another" (Milindapanha trans. by De Bary 1960 : 108-109). At every instant the old man vanishes, and a new man, caused by the first, comes into being. Even though this analogy is meant to explain the identity of a person, rebirth and the continuous link of the karma, it canalso illustrate the continuously changing 
substance while the identity of the form is still retained.

The identity of an object comprises not the physical appearance which is regarded as impermanent but the sp irit or the essence of it. The care given to ancient monuments in eastern countries indicates this belief. In China where Confucianism remains unshakable, the focus is on the genius loci, the spirit of the place, rather than on the details of the architecture (Wai $1989: 3-8)$. In the case of sacred architecture where a building is the representation of a god's dwelling, the existence of the deity is far more important than the fabric of the architecture. It is reported that in Tibetan monasteries, every sacred room built to house a different deity undergoes a the process of demolition and re-construction most of the time. If there is a sign indicating that the deity has left the dwelling place, for instance if cracks appear on the walls, the structure is demolished and re-built on the same site (Khosla 1975:81). The Shinto tradition of rebuilding shrine complexes at regular intervals still prevails in Japan. This special custom comes from the desire of the Japanese periodically to revitalize the deity. The reconstruction of a shrine is, in a sense, parallel to the agricultural cycle of growth from seed to harvest to renewal in the following spring (Ito cited in Larsen 1988 :16).

The characteristics of existence according to Buddhism form a basis for a Buddhist world-view that, in turn, constitutes the character of Thai Buddhists and their culture. As we have seen in the previous chapter, Buddhist monasteries are subject to extensive and continuous repair. The impermanent nature of building materials has been accepted as a part of the life of a building. Everything, mental and physical, has a beginning and an end, that arises and passes away. Contemplation of the way things are, of the law of nature, together with the act of devotion to the Lord Buddha results in an attitude towards monastic architecture which emphasises restoration rather than preservation of architectural fabric and its archaeological, historical, or authentic values. In the present situation, there are a number of factors that make the traditional way of caring for monuments acceptable only to a certain extent. While the Buddhist attitude towards monastic architecture still prevails, there are problems related to the technical aspects of conservation such as the lack of traditional craftsmen, the introduction of new building materials and construction methods, and change within the monasteries brought about by economic development. These problems lead to the loss of original historic fabric. The need for conservation of historical value, which had never been realized, became an important c riterion in caring for monuments.

\section{Concept of Authenticity}

The most controversial aspect of conservation philosophy is the determination of the authenticity of a historic fabric or place. This problem is unavoidable since a building or place must undergo a process of repair which leads to changes of material or structure. Throughout the history of conservation philosophy, we can see changes in attitude towards the integrity of historic fabric and what is considered to be the main criterion for judging the authenticity of historic buildings. The authenticity of a fabric has been interpreted differently according to the propagators.

The criterion for authenticity is, in a way, justified by the notion of what the past should be, as conceived by the people of that particular period. The notion of the 
past can be selective, since human beings have a tendency to choose and remember particular elements of the past that are relevant to them and reassure their present and future. Certain periods, styles, or relics are considered to be better interpretations of the past than others. It is suggested that when Victorian architects restored medieval churches, they reaffirmed ties with the past and made their churches more authentic by improving them. The fact that modern materials were used to replace the original ones did not falsify the medieval buildings but ".... it lent them the higher truth than their builders $h$ ad realized" ( Lowenthal 1992 : 88 ). Authenticity cannot be defined and is always difficult to achieve. It is a quality that is determined by the need for humans to certify the origins, purposes, and creators of our past inheritance.

Authenticity, it is suggested, can be the outcome of three fidelities: to original objects and materials, to original contexts, and to original aims (Lowenthal 1992: 82 ). However, if one aspect of authenticity is achieved, the others tend to be rendered less effective. In spite of contradiction, authenticity is essential and must be respected in every conservation activity. We will examine the concept of authenticity within the three types of fidelity, particularly in relation to architecture and its conservation.

\section{Material Authenticity}

It is obvious that in repairing historic monuments, the same kind of material must be used. The original materials should be preserved by sound maintenance, so that their uses can be prolonged as much as possible. In the case of wooden architecture, such as Thai monasteries, the survival of the original materials is a rare chance. The time span for wooden structures is relatively short. The structural and decorative elements have always been replaced through time. Repairing by replacing a part of the structure is common in countries with a timber tradition. In Japan, the attempt to retain the authenticity of a timber structure goes as far as the idea that the replaced timber should not only be of the same wood but also possess the same structural and aesthetic quality. The Japanese sometimes try to obtain new timber with the same natural defects as the old and decayed one ( Larsen n.d:chapter 3, p.8).

Lowenthal writes about the case of the ship of Theseus to illustrate the dilemma concerning material authenticity. The old ship was restored to sea-worthiness where each board was replaced by a new one until the entire ship was refurbished. At the same time, each of the old boards from the original ship was put into a new frame. Then, which of the boats can be considered original? It is suggested that, in this case, authenticity rests in 'identity' as a boat rather than a collection of old planks and that each new plank became a part of the old ship while the old ones were "...parts of a new ship just coming into being. Serving as parts of Theseus's original ship was only a temporary phase in the old planks' lifetime career" (Lowenthal 1992 : 82-83).

In this case, object identity received stronger c onsideration than material authenticity. But how far can this consideration go, and could it be justified in every case? Should material authenticity be sacrificed for other better causes? In Bergen, Norway, a row of eighteenth century houses burnt down. The Norwegian conservators decided to rebuild them in order to retain the integrity of the whole context. But instead of timber, concrete was used for the structure of the houses 
and was covered with timber weatherboards. The authenticity of materials and structure has gone completely. The argument for the concrete structure is that it is fire-safe. The intervention is justified because "...safely handing down the monument to the next generation is the main goal. Hopefully, even Ruskin would have agreed with this" ( Tschudi-Madsen $1985: 21$ ).

Object identity cannot always overcome the authenticity of material, particularly in the case where the material plays a special role in the architectural fabric. In Thai monastic architecture, a cho-fa, a roof decoration, forms a finial to the roof structure. Its form and meaning are derived not only from the functional necessity of the wooden structure but also from fundamental religious beliefs. A Cho-fa is made from a large piece of hard wood, sculpted into a delicate abstract form symbolizing a Naga, a mythical serpent. The sculpted wood is then coated with layers of lacquer made from natural resin, to form a protective coat and a base for gold-gilding. The Cho-fa is considered to be the most important decorative element of the whole building. Areligious ritual as well as secular celebrations are carried out when the principle cho-fa is installed in its place. Traditional craftsmen took pride in the making of the cho-fa, since it needs skill and experience to achieve a beautiful and well-proportioned element.

The Cho-fa is one of the elements most prone to unnoticed deterioration, since its location is not easily accessible. When the damage becomes apparent, it is always too late to repair it. It has become an almost acceptable way of repairing nowadays for the damaged element to be replaced by a new one made from modern materials such as concrete or fibreglass. Since the moulding process is easy to execute, in conjunction with the soaring price of timber, the use of cho-fa made from new materials is e conomically advantageous. However, to scarify the authenticity of material for the sake of economicsalone is not justifiable. The loss is not only in the authenticity but also the demeaning of the original craftsmanship, the development of the timber tradition, and the symbolic representation of the element. In this case, form and financial benefit cannot overrule the material authenticity.

\section{Authenticity of the Aims}

In art, aims refer to the aims of the artists who created the original work of art. In the case of historic monuments it can be the design intentions. It is mentioned in the Guidelines of World Cultural Heritage Sites that in the case of architecture built from vulnerable materials, the same types of materials and traditional skills should be used for the restoration of the decayed parts. This is because "...the preservation of the design intentions and details is just as important as the preservation of original material" (Feilden \& Jokilehto 1993 : 71).

At the end of 1988 , a major restoration was carried out on the four main stupas of Wat Po. During the intervention, valuable art objects, Buddhist scriptures, and Buddha images were found encased in two of the stupas. The finds were recorded by the Department of Fine Arts who decided that they should be kept in a safe place and displayed to the public. Since Wat Po is one of the most important royal monasteries, a report of the find was sent to the king whom the Department also asked for advice on how the objects should be treated.

It is an ancient tradition that objects of symbolic value are installed within a stupa. The scriptures (the Tri pitaka), found at 
Wat Po were inscribed on sheets of gold. They are a representation of the Dhamma, the teaching of the Buddha. Therefore, the stupas were intended to be not only a Thatu Chetiya but also a Dhamma Chetiya. The advice from the king illustrates the importance of conserving the original intention of the structure. The Department was advised to keep all the objects in the monastery museum. Replicas of the art objects and the scriptures would be made and reinstated in the stupas so that the restored stupas would retain their original symbolic function as both Thatu Chetiya and Dhamma Chetiya.

The deterioration of materials as a result of natural environmental processes can deprive a building of its original intention. An intention of a Buddhist temple is the transference of the heavenly world to the earth. The Buddhavas is a cosmological model where an ubosot and a vihara represent the sacred realms where man and the transcendental power of the Buddha can meet. This concept is clearly represented in the planning and the highly ornate character of the buildings in the Buddhavas area. The gables and pediments of a n ubosot and vihara are decorated with reliefs, covered in paint, gilding, or mirror tiles. Window shutters and doors may be carved in relief and finished with gold leaf, or inset with mother of pearl. The effect of the transcendental realm is achieved by natural light reflected on the glittering surfaces as well as the high contrast of colours and textures under the tropical sky. When we look at a Buddhist temple, we not only appreciate its space, form, and proportion but also the decorative elements that constitute the texture and colour of the architectural fabric. Replacement of flaking gold and dull coloured glass, when the damage to the materials has gone beyond the point where they can be considered a part of the 'patina of age', with the same materials and equally high workmanship can be seen as justified.

\section{Authenticity of the context}

It is stated in Lowenthal that "many creations are consciously or inadvertently infused with context" and that the removal of a work of art from its context to a museum "deprives it of vital environmental context" (Lowenthal 1992: 83). It is arguable that works of art are sometimes more accessible and better absorbed in a museum e nvironment. However, in order to fully understand the meaning of architecture, especially living monuments such as Thai monasteries, one needs context to understand what one experiences as well as to establish a meaningful relationship between man and the environment. The context can be interpreted as physical as well as cultural and social. These entities are subjected to change, since repair, restoration and reconstruction have been carried out throughout the history of the monastery. However, it is the encroachment of modern development that causes much damage to the physical context of the monastery. One can witness examples of infidelity to the authenticity of the context where ancient stupas stand cheek by jowl with new multi-storey shophouses and monastic complexes a re surrounded by concrete parking lots.

\section{Conclusion}

"All things are preceded by mind, governed by mind and are the creation of the mind " (The Dhammapada).

Buddhism teaches that things are created by 'mind' rather than by the mind perceiving existing things. Buddhist per- 
ception is concerned with interpreting the value of a thing rather than describing it as fact. This ideology results in the difference between Buddhist and western art which often depicts the realistic and the materialistic. The Buddha image is the best example of Buddhist art. An artist creates an image to be a representation of a super-human and supernatural iconography. The image is not a portrait but a symbol of 'the Great Person' in human form, while western artists, such as the Greeks, use the artistic idea of human form to express the characteristics of their gods. Images of the Buddha were made because there was a need to represent the Buddha, not because there was a demand for 'art' (Coomaraswamy 1977 :164).

Buddhist ideology also expresses the attitude that the 'place' where spiritual experience occurs is more important than the material representation of the place. However, the spirit of the place is felt both through the physical reality of the architecture and the spiritual quality of the place. It is necessary to maintain the balance between the material and the spiritual elements, since they depend upon each other as two sides of the same coin.

Even though traditional restoration is based on Buddhist ideology, we cannot justify the act of restoration without regarding the historical value of buildings as evidence of past civilizations. Traditional restoration and development of stylesthrough restoring and re-building, is no longer possible in the present situation. There were few changes in materials, building technology and architectural style from the thirteenth to the nineteenth centuries. Traditional construction techniques were practised until the introduction of modern technology; due to changes of the past three decades, we have seen the loss of many historical structures. Thus, before any intervention in conservation is undertaken, a monument should undergo evaluation of both its cultural and socio-economic value. These values that determine the spirit of the place and the essence of the religious art object should be considered the most important to maintain.

\section{References}

Conze, Edward. Buddhist Texts Through the Ages. Oxford: Bruno Cassirer, 1954.

Buddhism: Its E ssence and Development. Oxford: Bruno Cassirer, 1951.

Coomaraswamy, Ananda. Selected Papers: Traditional Art and Symbolism. Edt. By Roger Lipsey. New Jersey: Princeton University Press, 1977.

Dellheim, Charles. The Face of the Past: The Preservation of the Medieval Inheritance in Victorian England. Cambridge: Cambridge University Press, 1982.

Dillstone, F.W. Christianity and Symbolism. London: Collins, 1955.

Eliade, Mircea. The Sacred and the Profane: The Nature of Religion. Trans. By Willard R. Trask. New York: Harper and Brother, 1961. Images and Symbols: Studies in Religion Symbolism, New York: Sheed and ward, 1962.

Feilden, B ernard M.\& Jokilehto, Jukka. Management Guidelines for World Heritage Sites. Rome:ICCROM, 1993.

Guenon, Rene. Crisis of the Modern World. Trans. By Marco P allis and R ichard Nicholson. London: Luzac and Co.ltd., 1975.

Humphreys, Chrismas. Buddhism: An Introduction and Guide. London: Penguin Books, 1990.

Jokilehto, Jukka Ilmari. A History of Architectural C onservation, D.Phil. Thesis, The University of York, Institute of AdvancedArchitectural Studies, Vol.1, 1986.

Khosla, Romi. Architecture and Symbolism in Tibetian Monasteries. In Shelter, Sign and Symbol. Edt. by Paul Oliver. London: Barrie\& Jenkins, 1975. 
Larsen, Knut Einar. Impression of Japanese Preservation Efforts. In ICOMOS Information, No.3 pp. 7-16, 1988.

Ling Trevor. The Buddha: Buddhist Civilization in India and Ceylon. London: Temple Smith, 1973.

Lopez, Donald S. Buddhism in Practice. New Jersey: Princeton University Press, 1995.

Lowenthal, David. Counterfeit Art: Authentic Fake? In International Journal of Cultural Property, No.1, Vol. 1.Pp79-103, 1992.

The Past is a Foreign Country. Cambridge: Cambridge University Press, 1990.

Menon, A.G. Krishna. Rethinking the Venice Charter: The Indian Experience: In South Asian Studies. No.10, 1994.

Mumford, Lewis. The Condition of Man. London: Mercury Books, 1963

Nakamura, Hajime.

Ways of Thinking of Eastern People: IndiaChina-Tibet-Japan. Honolulu: University of Hawaii Press, 1971.

Tambiah, S.J. World Conqueror and World Renouncer: A Study of Buddhism and Polity in Thailand against a Historical Background. Cambridge: Cambridge University Press, 1977.

Tschudi-Madsen, Stephen. Principles in Practice: Reflections on the Conservation of Wooden Architecture. In ICOMOS Information. Vol.4.pp. 18-24, 1989.

Wei, C. and Aass, A. Heritage Conservation East and West. In ICOMOS Information 3,1989 .

\section{Translated Pali and Sanskrit Texts}

The Dhammapada Trans. By Narada Thera. London: John Murray, 1959.

\section{Bibliography in Thai}

Vallibhotama, Srisakra. From King U-Thong to King P rasart -Thong. I n M aung Boran Journal, Vol. 7, No. 3. Bangkok: Maung Boran Publishing, 1990. 